\title{
PERANCANGAN SISTEM INFORMASI AKUNTANSI PENERIMAAN DAN PENGELUARAN KAS BERBASIS WEB PADA PT POS INDONESIA (PERSERO) KOTA JAMBI
}

\author{
Kristeria ${ }^{1}$ \\ kriskristeria@gmail.com \\ Ayu Feranika \\ ayuferanika2@gmail.com \\ Gunardi \\ gun4rdi.sj@gmail.com \\ Program Studi Komputerisasi Akuntansi \\ Universitas Dinamika Bangsa
}

\begin{abstract}
PT. Pos Indonesia (Persero) Jambi City is one of the State-Owned Enterprises (SOEs) which is engaged in the largest services and spread across the country, by applying the principles of limited corporations, Weaknesses of PT. Pos Indonesia (Persero) Jambi City has not yet been approved in computerized activities for recording cash receipts and disbursements such as the use of Basar Books, as well as the use of default applications such as Microsoft Excel, which requires a relatively long usage time, both of which are complementary to report generation. To overcome this problem, a web-based cash receipt and expenditure accounting information system was created at PT. Pos Indonesia (Persero) Jambi City using the waterfall system development method. Data collection uses observation, interview, and literature study techniques. The results of this study resulted in the application of an accounting system for cash receipts and uses at PT. Pos Indonesia (Persero) Jambi City. Enabling assistance makes it easier for employees to manage cash receipt data and open cash, accelerate the presentation of reports and facilitate the process of finding cash data in and cash out at PT. Pos Indonesia (Persero) Jambi City.
\end{abstract}

Keywords : Accounting information system, Cash Receipt, Cash Disbursement.

\section{ABSTRAK}

PT. Pos Indonesia (Persero) Kota Jambi merupakan salah satu Badan Usaha Milik Negara (BUMN) yang bergerak dibidang jasa pelayanan terbesar dan tersebar polosok tanah air, dengan menerapkan prinsip-prinsip perseroan terbatas, Kelemahan PT. Pos Indonesia (Persero) Kota Jambi dalam akvitas pencatatan penerimaan dan pengeluaran kas belum sepenuhnya terkomputerisasi seperti penggunaan Buku Basar, serta penggunaan aplikasi bawaan yaitu Microsoft Excel, sehingga membutuhkan waktu yang relatif lama, baik dari segi perhitungan hingga pembuatan laporan. Untuk mengatasi permaslahan tersebut, maka dibangun sistem informasi akuntansi penerimaan dan pengeluaran kas berbasis web pada PT. Pos Indonesia (Persero) Kota Jambi dengan menggunakan metode pengembangan sistem waterfall. Pengumpulan data menggunakan teknik observasi, wawancara, dan studi pustaka. Hasil penelitian ini menghasilkan aplikasi sistem akuntansi penerimaan dan pengeluaran kas pada PT. Pos Indonesia (Persero) Kota Jambi. Sehingga membantu memudahkan karyawan dalam pengelolaan data penerimaan kas dan pengeluaran kas, mempercepat dalam penyajian laporan dan mempermudah dalam proses pencarian data kas masuk dan kas keluar pada PT. Pos Indonesia (Persero) Kota Jambi.

Kata Kunci : Sistem Informasi Akuntansi, Penerimaan Kas, Pengeluaran Kas.

\section{PENDAHULUAN}

\section{LatarBelakang}

Perkembangan ilmu pengetahuan dan teknologi informasi yang pesat telah menjadi salah satu faktor pendorong yang memiliki peranan yang sangat penting dalam perkembangan perekonomian dunia, oleh karna itu perusahaan membangun sebuah sistem informasi yang dapat mengolah operasional perusahaan. PT. Pos Indonesia (Persero) Kota 
Jambi merupakan salah satu Badan Usaha Milik Negara (BUMN) yang bergerak dibidang jasa pelayanan terbesar dan tersebar polosok tanah air, dengan menerapkan prinsip-prinsip perseroan terbatas. Kelemahan PT. Pos Indonesia (Persero) Kota Jambi dalam akvitas pencatatan penerimaan dan pengeluaran kas belum sepenuhnya terkomputerisasi seperti penggunaan buku besar, serta penggunaan aplikasi bawaan yaitu Microsoft Excel, sehingga membutuhkan waktu yang relatif lama, baik dari segi perhitungan hingga pembuatan laporan. Sistem seperti ini dinilai kurang efektif karena proses pengimputan data cukup memakan waktu sehingga dapat mengakibatkan terjadinya penumpukan dokumen dan juga mempersulit bagian keuangan dalam mencari data yang dibutuhkan.

Sistem Penerimaan kas pada PT. Pos Indonesia (Persero) yang berasal dari pendapatan pengiriman surat, penjualan perangko, penjualan materai, pengiriman wesel, dan paket sedangkan menurut Sujarweni (2015:123) dalam Diana, dkk (2018:18) sistem akuntansi pengeluaran kas merupakan sistem yang membahas keluarnya uang yang digunakan untuk pembelian tunai maupun kredit dan untuk pembayaran. Pengeluaran kas yang dilakukan oleh PT. Pos Indonesia (Persero) kota Jambi yaitu, gaji karyawan, bbm genset, transport dan pembayaran lainnya.

Prosedur penerimaan dan pengeluaran kas bagian loket menyetorkan sejumlah uang tunai dan bukti pembayaran yang diperoleh dari semua setoran, kemudian diserahkan ke kasir internal, selanjutnya kasir internal mencatat data transaksi penerimaan kas ke dalam buku besar, kemudian diserahkan kepada bagian akuntansi untuk memeriksa traksaksi penerimaandan pengeluaran kas dan diserahkan kembali dibagian loket. Penyimpanan bukti penerimaan dan pengeluaran kas belum sepenuhnya terkomputerisasi, hal tersebut menjadi kendala ketika pencarian data saat dibutuhkan karena dokumen tersebut ditumpuk sehingga penyampaian informasi yang dibutuhkan bagian akuntansi dan pimpinan seringkali mengalami keterlambatan, jika penerimaan dan pengeluaran kas dilakukan sudah sepenuhnya terkomputerisasi diharapkan akan meningkatkan efektivitas dan efesiensi waktu kerja dan meminimalisir kesalahan pencatatan seperti, pencatatan ganda, dokumen hilang atau tercecer. Hal tersebut dapat memudahkan karyawan dalam pengolahan data penerimaan dan pengeluaran kas, mempercepat dalam penyajian laporan dan mempermudah dalam proses pencarian dana kas masuk dan dana kas keluar pada PT Pos Indonesia (Persero) Kota Jambi. maka dari itulah, penelitian ini ditunjukkan untuk merancang sistem informasi akuntansi penerimaan dan pengeluaran kas berbasis web pada PT. Pos Indonesia (Persero) Jambi.

\section{Permasalahan}

Berdasarkan latar belakang diatas maka permasalahan yang akan dikaji dalam penelitian ini adalah sebagai berikut :

1. Bagaimana sistem informasi akuntansi penerimaan dan pengeluaran kasyang telah digunakan oleh PT Pos Indonesia (Persero) Kota Jambi?

2. Bagaimana peracangan sistem informasi penerimaan dan pengeluaran kas berbasis web yang dapat diimplementasikan dan sesuai dengan kebutuhan PT. Pos Indonesia (Persero) Kota Jambi ?

\section{Tujuan}

berikut :

Tujuan penelitian ini adalah sebagai

1. Mengetahui sistem informasi akuntansi penerimaan dan pengeluaran kas yang digunakan oleh PT Pos Indonesia (Persero) Kota Jambi.

2. Merancang sistem informasi akuntansi penerimaan dan pengeluaran kas berbasis web yang dapat diimplementasikan dan sesuai dengan kebutuhan PT. Pos Indonesia (Persero)Kota Jambi.

\section{TINJAUAN PUSTAKA \\ Sistem}

Menurut Diana, dkk (2018:4) sistem adalah kumpulan orang yang saling bekerja sama dengan ketentuan-ketentuan aturan yang sistematis dan terstruktur untuk 
membentuk satu kesatuan yang melaksanakan suatu fungsi untuk mencapai tujuan. Sedangkan menurut Sri (2016:11) sistem adalah dari dua dua atau lebih komponen yang saling bekerja dan berhubungan untuk mencapai tujuan tertentu.

\section{Informasi}

Menurut Sri (2016:12) informasi merupakan data yang sudah diolah yang ditujukan untuk seseorang, organisasi ataupun siapa saja yang membutuhkan.

\section{Akuntansi}

Menurut Hery (2015:6) akuntansi adalah seni pencatatan, penggolongan, pengikhtisaran, dan pelaporan atas suatu transaksi dengan cara sedemikian rupa, sistematis dari segi isi, dan berdasarkan standar yang diakui umum.

\section{Sistem Informasi Akuntansi}

Menurut American Accounting Association Sistem Informasi Akuntansi (SIA) merupakan proses mengidentifikasi, mengukur, dan melaporkan informasi ekonomi untuk memungkinkan adanya penilaian dan keputusan yang jelas dan tegas bagi mereka yang menggunakan informasi tersebut.

\section{Penerimaan Kas}

Menurut Hery (2015:35) penerimaan kas (cash receipts journal) adalah digunakan untuk mencatat seluruh transaksi penerimaan kas. Penerimaan kas dari perusahaan berasal dari dua sumber utama yaitu dari penjualan tunai dan dari piutang. Penerimaan kas dari penjualan tunai dapat berupa uang tunai credit card sele sip, atau cek pribadi (personal check). Penerimaan kas dari piutang dapat berupa cek atau giro bilyet (Mulyadi, 2001 dalam Saifudin dan Firda, 2017:126).

\section{Pengeluaran Kas}

Pengeluaran kas adalah suatu transaksi yang menimbulkan berkurangnya saldo kas dan bank milik perusahaan yang diakibatkan adanya pembelian tunai, pembayaran utang maupun hasil transaksi yang menyebabkan berkurangnya kas (Soemarso S.R, 2004 dalam Fatahreza, 2017:16).
Penerimaan dan Pengeluaran Kas di PT. Pos Persero (Indonesia) Jambi

Penerimaan kas pada PT. Pos Indonesia (Persero) yang berasal dari pendapatan pengiriman surat, penjualan perangko, penjualan materai, pengiriman wesel, dan paket. Pengeluaran kas yang dilakukan oleh PT. Pos Indonesia (Persero) kota Jambi yaitu, gaji karyawan, bbm genset, transport dan pembayaran lainnya.

\section{Prosedur Yang Sedang Berjalan di PT. Pos Persero (Indonesia) Jambi}

PT. Pos Indonesia (Persero) Kota Jambi dalam kegiatan pencatatan penerimaan dan pengeluaran kas belum sepenuhnya terkomputerisasi seperti penggunaan Buku Besar, serta penggunaan aplikasi bawaan yaitu Microsoft Excel, sehingga membutuhkan waktu yang relatif lama, baik dari segi perhitungan hingga pembuatan laporan.

\section{Prosedur Penerimaan dan Pengeluaran Kas di PT. Pos Persero (Indonesia) Jambi}

1. Bagian loket menyetorkan sejumlah uang tunai dan bukti pembayaran yang diperoleh dari semua setoran.

2. Diserahkan ke kasir internal, selanjutnya kasir internal mencatat data transaksi penerimaan kas ke dalam buku besar.

3. Kemudian diserahkan kepada bagian akuntansi untuk memeriksa traksaksi penerimaan dan pengeluaran kas, dan diserahkan kembali dibagian loket.

\section{METODE PENELITIAN}

Lokasi penelitian adalah salah satu instansi Badan Usaha Milik Negara (BUMN) yaitu PT. Pos Indonesia (Persero) Kota Jambi yang terletak di Jl. Sultan Thaha No. 5 Pasar Jambi, Kec. Pasar Jambi. Objek dalam penelitian ini segala sesuatu yang berhubungan dengan sistem informasi akuntansi penerimaan dan pengeluaran pada PT Pos Indonesia (Persero) Kota Jambi. Perangkat keras yang digunakan mencakup perangkat keras (motherboar, processor, VGA dan lainnya) yang disatukan di sebuah komputer. 
Alat bantu pemodelan sistem yang digunakan ; Unified Modeling Language (UML), Use Case Diagram, Diagram Aktivitas (Activity Diagram), Diagram Kelas (Class Diagram). Adapun kerangka kerja penelitian yang di gunakan seperti gambar 3.1 :

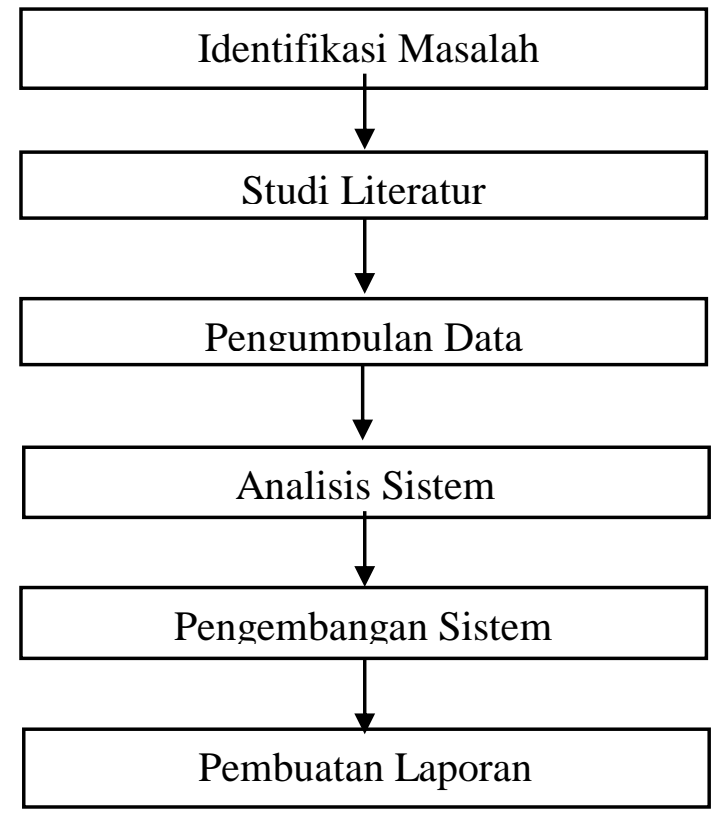

Gambar 3.1 Kerangka Kerja Penelitian

Pengumpulan Data

Pada tahapan ini penulis melakukan pengumpulan data untuk mendapatkan data dan informasi, yaitu sebagai berikut ; Pengamatan (Observation), Wawancara (Interview), Pengumpulan sampel data (Sampling).

Pengembangan Sistem

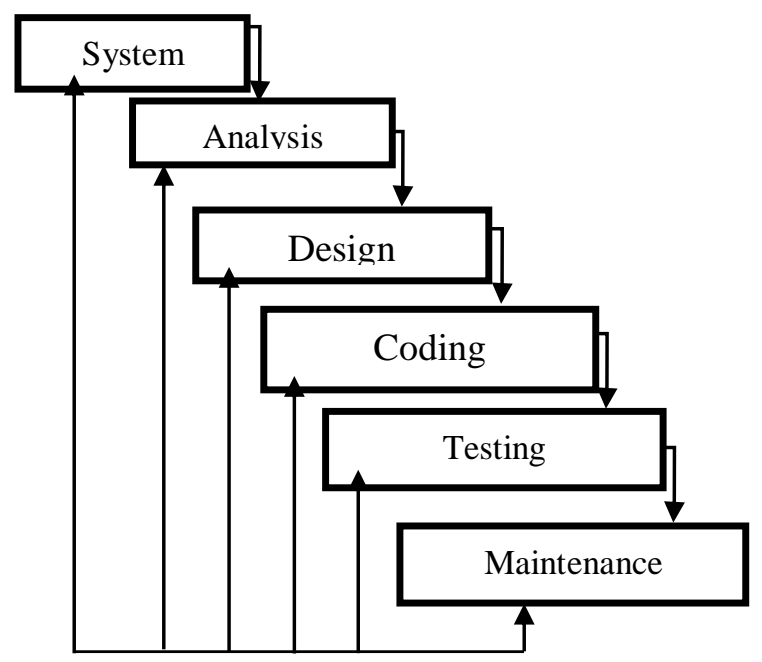

Gambar 3.2 Pengembangan Sistem

\section{HASIL DAN PEMBAHASAN}

Untuk perancangan proses sistem pada sistem informasi akuntansi penerimaan dan pengeluaran kas ini digunakan metode use case diagram. Pada diagram ini dijelaskan proses kerja sistem informasi akuntansi penerimaan dan pengeluaran dapat dilihat pada gambar 4.1 sebagai berikut : 
Account: Vol 6 No 2. Kristeria, Ayu Feranika, Gunardi,

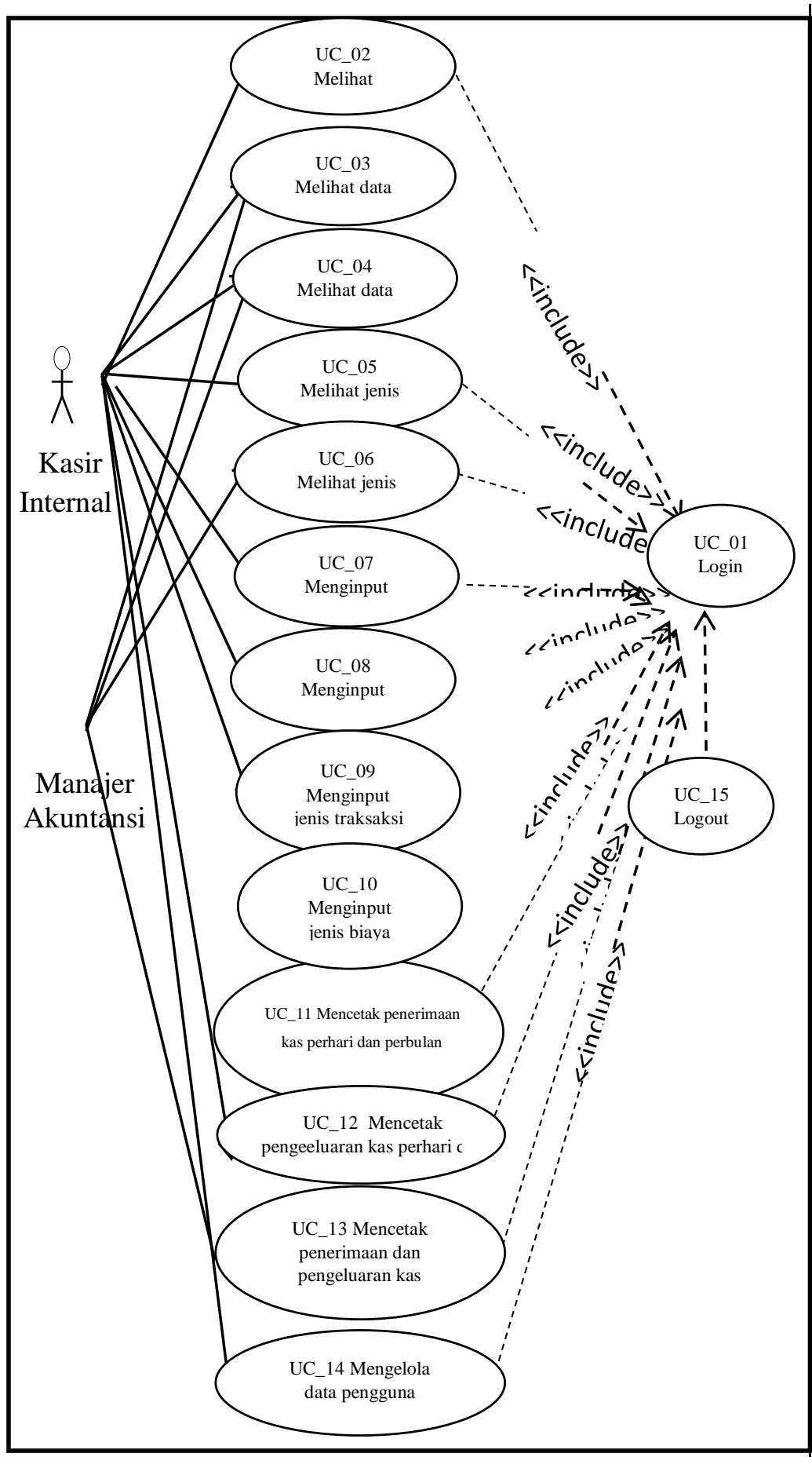

Hasil implementasi rancangan input berupa halaman input yang ada pada sistem informasi akutansi penerimaan kas penjualan koran asongan yang penulis buat dalam penelitian ini. Adapun halaman input tersebut adalah sebagai berikut :

\section{Tampilan Form Login}

Pada tampilan form login, agar dapat masuk ke dalam sistem, aktor harus login terlebih dahulu, dengan memasukan username dan password. Tampilan form login dapat dilihat pada gambar 4.2 berikut ini:

\section{SPOS INDONESIA}

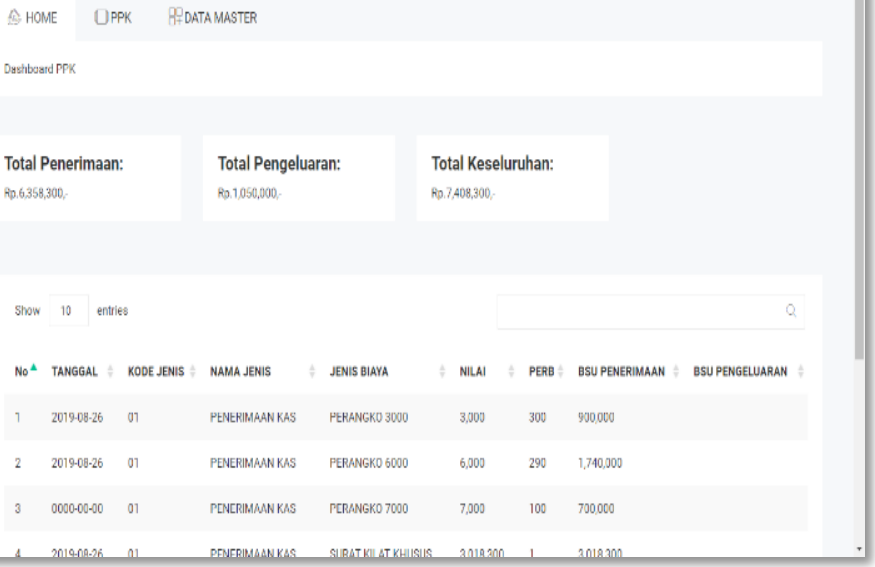

Gambar 4.2 Tampilan Form Login

\section{Tampilan Dashboard}

Pada dashboard atau tampilan halaman utama terdapat beberapa menu yang dapat dibuka oleh aktor seperti input penerimaan kas, input pengeluaran kas, input data pengguna, dan log out. Berikut ini tampilan dari halaman utama yang dapat dilihat pada gambar 4.3:

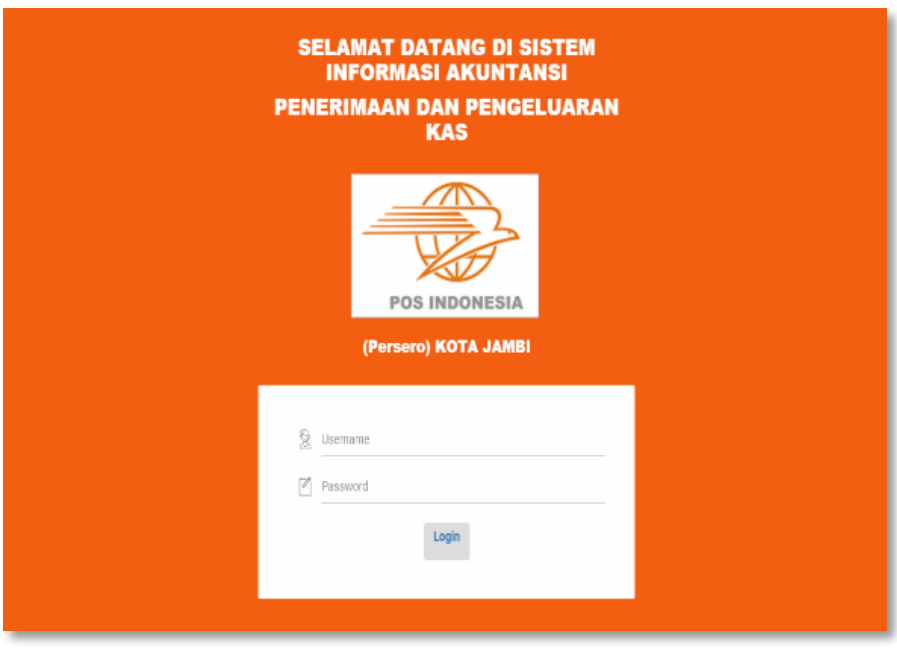

Gambar 4.3 Tampilan Dashboard 
3. Tampilan Form Input Data Penerimaan Kas

Pada form input data peneirmaan ini, aktor dapat menginput data-data yang sesuai dengan data penerimaan kas PT. Pos Indonesia (persero) Kota Jambi. Tampilan form input data penerimaan dapat dilihat pada gambar 4.4 berikut ini:

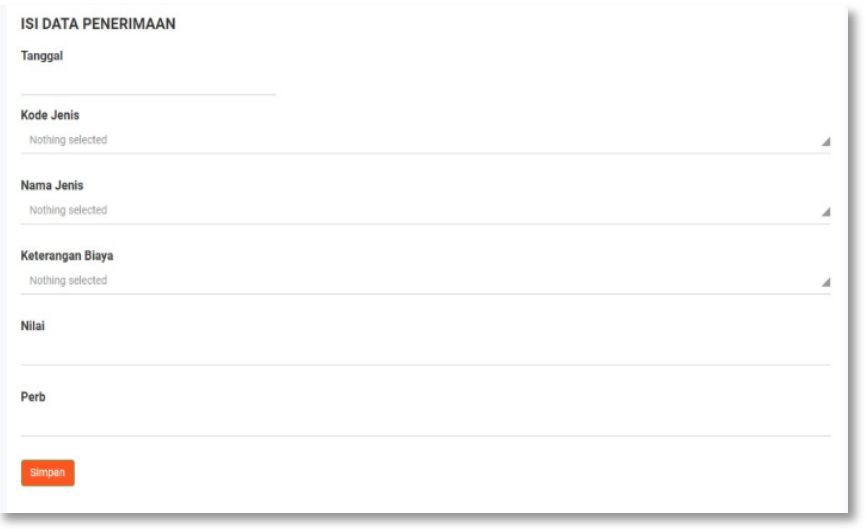

Gambar 4.4 Tampilan Form Input Penerimaan Kas

4. Tampilan Form Input Data Pengeluaran Kas

Pada form input data pengeluaran ini, aktor dapat menginput data-data yang sesuai dengan data pengeluaran kas PT. Pos Indonesia (persero) Kota Jambi. Tampilan form input data pengeluaran dapat dilihat pada gambar 4.5 berikut ini:

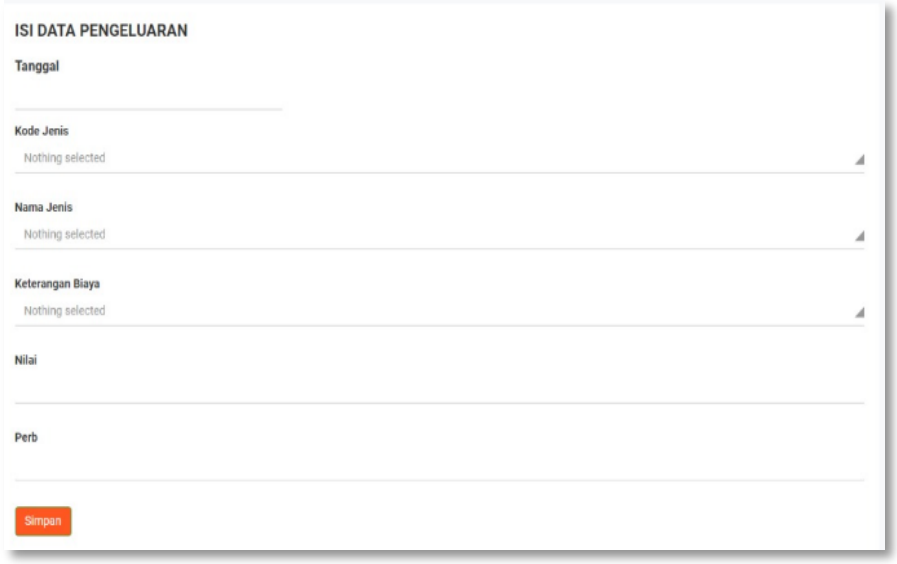

\section{Gambar 4.5 Tampilan Form Input Pengeluaran Kas}

\section{Tampilan Form Input Jenis Transaksi}

Pada form input jenis transaksi ini, aktor dapat menginput data-data yang sesuai dengan data jenis transaksi pada PT. Pos Indonesia (persero) Kota Jambi. Tampilan form input jenis transaksi dapat dilihat pada gambar 4.6 berikut ini:

ISI DATA TRANSAKSI

Kode Jenis

Nama Jenis

\section{Simpan}

\section{Gambar 4.6 Tampilan Form Input Jenis Transaksi}

\section{Tampilan Form Input Jenis Biaya}

Pada form input jenis biaya ini, aktor dapat menginput data-data yang sesuai dengan data jenis biaya pada PT. Pos Indonesia (persero) Kota Jambi. Tampilan form input jenis biaya dapat dilihat pada gambar 4.7 berikut ini :

ISI DATA JENIS BIAYA

Kode Jenis Biaya

Jenis Biaya
Gambar 4.7 Tampilan Form Input Jenis Biaya 
7. Tampilan Form Input Data Pengguna

Pada form inputdata pengguna ini, aktor dapat menginputusername, password, level, dan email untuk menambah admin atau user pada sistem informasi penerimaan dan pengeluaran kas pada PT. Pos Indonesia (persero) Kota Jambi. Tampilan form input data pengguna dapat dilihat pada gambar 4.8 berikut ini:

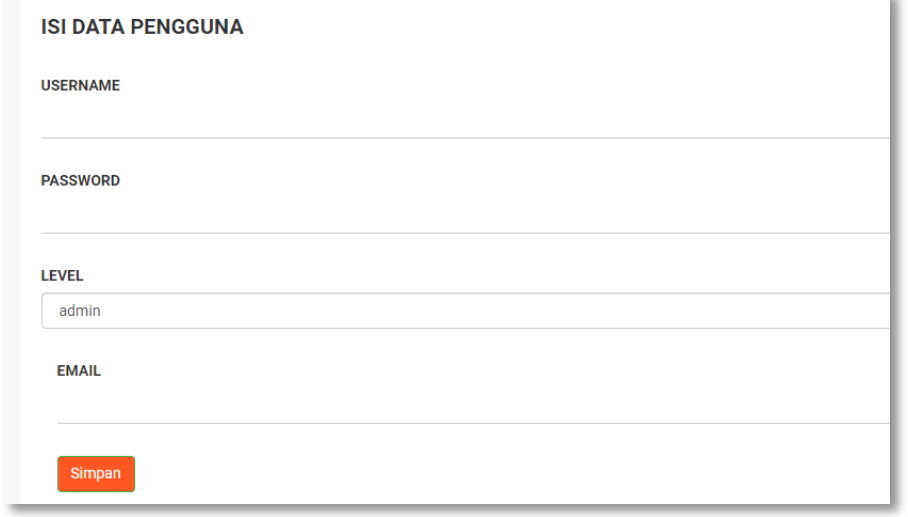

\section{Gambar 4.8 Tampilan Form Input Data Pengguna}

\section{Tampilan Form Edit Data Penerimaan Kas}

Pada form edit penerimaan ini, aktor dapat mengedit data-data yang sesuai dengan data penerimaan kas PT. Pos Indonesia (persero) Kota Jambi. Tampilan form edit data penerimaan dapat dilihat pada gambar 4.9 berikut ini :

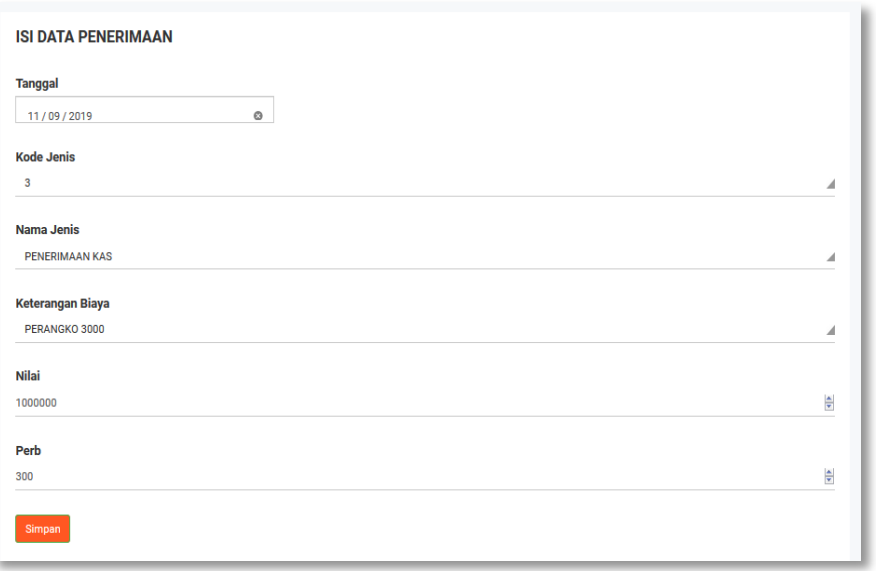

Gambar 4.9 Tampilan Form Edit Penerimaan Kas

\section{Tampilan Form Edit Data Pengeluaran}

Pada form edit penerimaan ini, aktor dapat mengedit data-data yang sesuai dengan data penerimaan kas PT. Pos Indonesia (persero) Kota Jambi. Tampilan form edit data penerimaan dapat dilihat pada gambar 4.10 berikut ini:

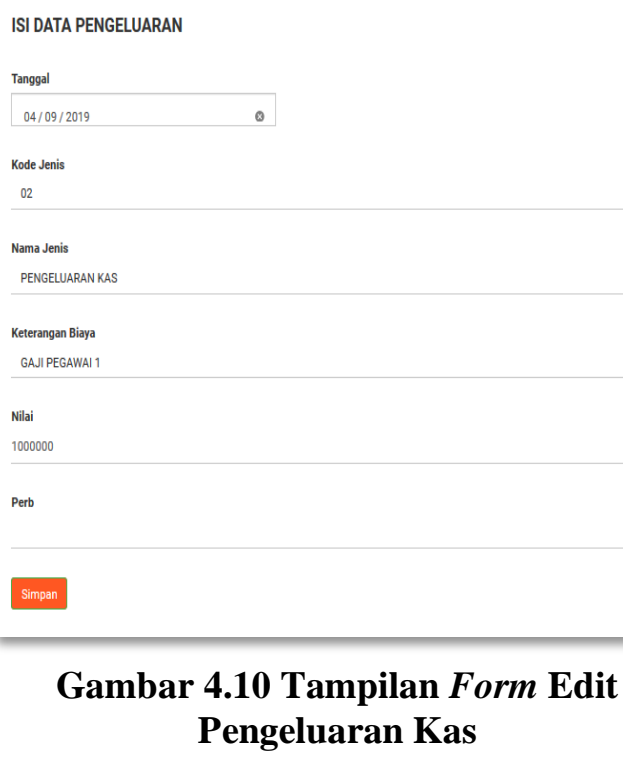

10. Tampilan Form Edit Jenis Transaksi

Pada form edit jenis transaksi ini, aktor dapat mengedit data-data yang sesuai dengan jenis transaksi PT. Pos Indonesia (persero) Kota Jambi. Tampilan form edit jenis transaksi dapat dilihat pada gambar 4.11 berikut ini:

\section{ISI DATA TRANSAKSI}

Kode Jenis

Nama Jenis

\section{Simpan}

Gambar 4.11 Tampilan Form Edit Jenis Transaksi 


\section{Tampilan Form Jenis Biaya}

Pada form edit jenis biaya ini, aktor dapat mengedit data-data yang sesuai dengan jenis biaya PT. Pos Indonesia (persero) Kota Jambi. Tampilan form edit jenis biaya dapat dilihat pada gambar 4.12 berikut ini:

\section{ISI DATA JENIS BIAYA}

Kode Jenis Biaya

Jenis Biaya

\section{Gambar 4.12 Tampilan Form Edit Jenis Biaya}

\section{Tampilan Form Edit Data Pengguna}

Pada form edit data pengguna ini, aktor dapat menginput username, password, level, dan email untuk menambah admin atau user pada sistem informasi penerimaan dan pengeluaran kas pada PT. Pos Indonesia (persero) Kota Jambi. Tampilan form edit data pengguna dapat dilihat pada gambar 4.13 berikut ini:

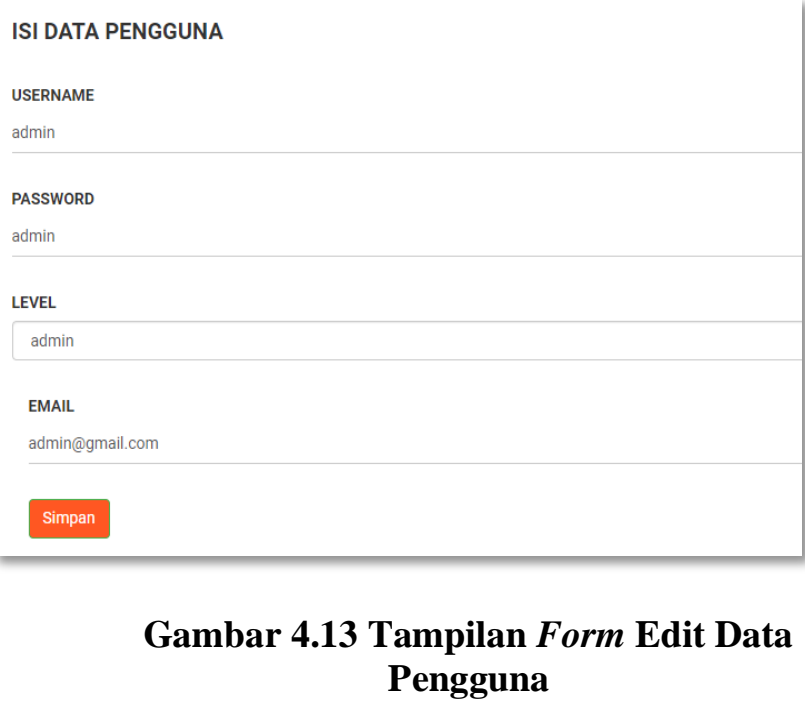

\section{Hasil Implementasi Rancangan Output}

1. Tampilan Output Data Penerimaan

Tampilan output data penerimaan merupakan halaman yang digunakan oleh aktor untuk melihat data penerimaan kas PT. Pos Indonesia (persero) Kota Jambi. Adapun tampilan data penerimaan dapat dilihat pada gambar 4.14 berikut ini:

\section{POS INDONESIA}

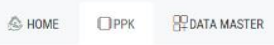

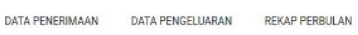
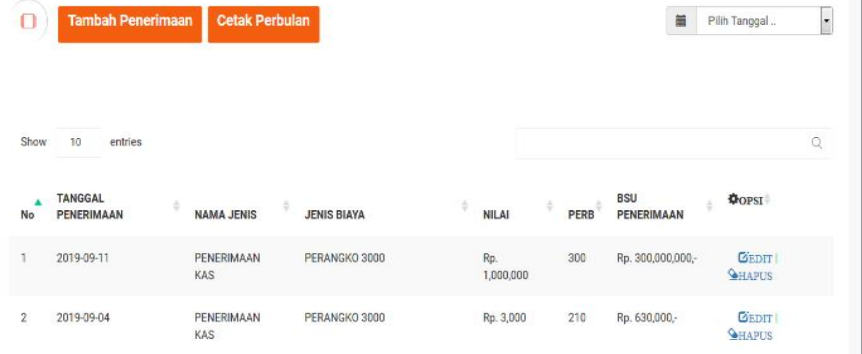

\section{Gambar 4.14 Tampilan Output Data Penerimaan}

\section{Tampilan Output Data Pengeluaran}

Tampilan output data pengeluaran merupakan halaman yang digunakan oleh aktor untuk melihat data pengeluaran kas PT. Pos Indonesia (persero) Kota Jambi. Adapun tampilan data pengeluaran dapat dilihat pada gambar 4.15 berikut ini:

\section{POS INDONESIA}
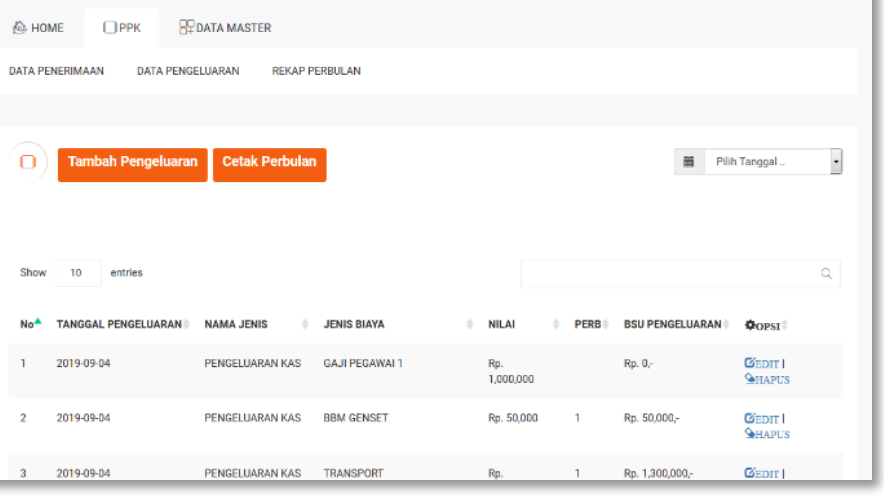

Gambar 4.15 Output Data Pengeluaran 


\section{Tampilan Output Jenis Transaksi}

Tampilan output jenis transaksi merupakan halaman yang digunakan oleh admin untuk melihat jenis Transaksi yang dapat masuk ke sistem penerimaan dan pengeluaran kas PT. Pos Indonesia (persero) Kota Jambi. Adapun tampilan jenis transaksi dapat dilihat pada gambar 4.16 berikut ini:

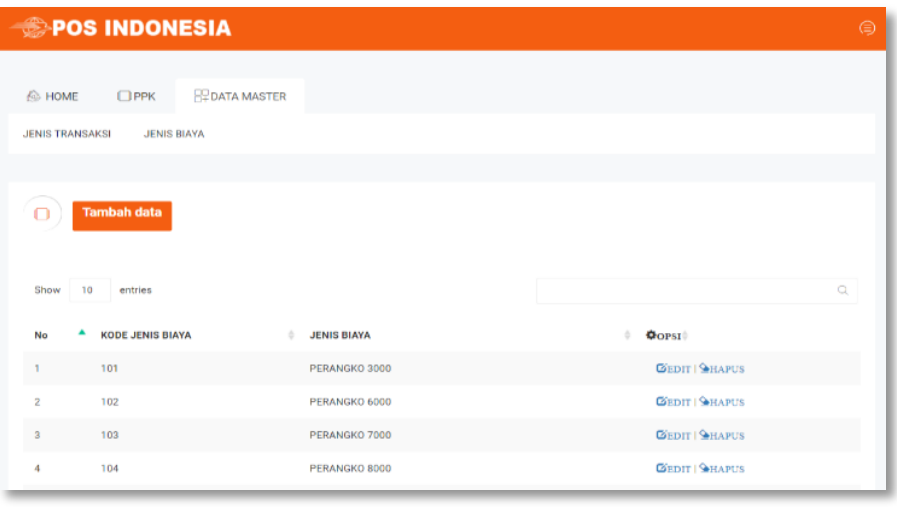

Gambar 4.16 Tampilan Output Jenis Transaksi

\section{Tampilan Output Jenis Biaya}

Tampilan output jenis biaya merupakan halaman yang digunakan oleh admin untuk melihat jenis biaya yang dapat masuk ke sistem penerimaan dan pengeluaran kas PT. Pos Indonesia (persero) Kota Jambi. Adapun tampilan jenis biaya dapat dilihat pada gambar 4.17 berikut ini:

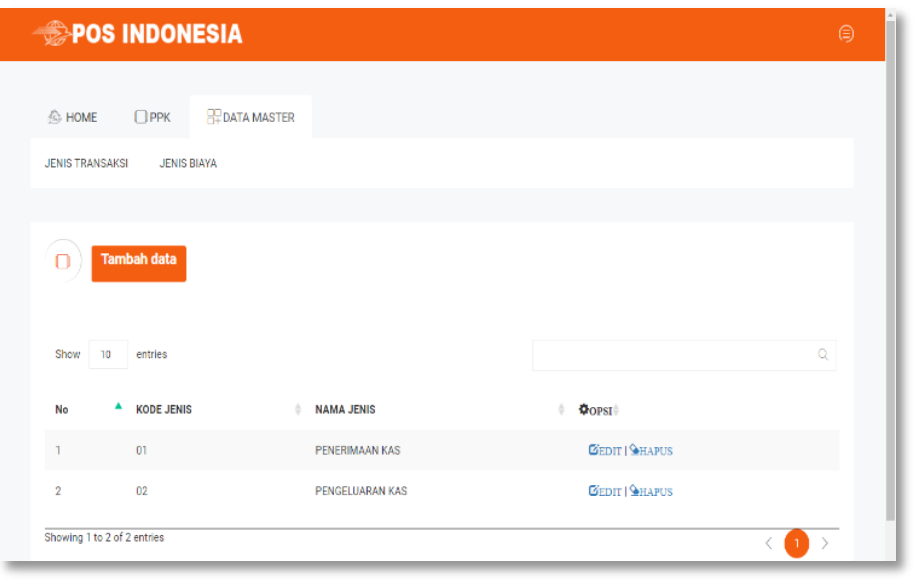

Gambar 4.17 Tampilan Output Jenis Biaya

\section{Tampilan Output Data Pengguna}

Tampilan output data pengguna merupakan halaman yang digunakan oleh admin untuk melihat data pengguna yang dapat masuk ke sistem penerimaan dan pengeluaran kas PT.

\section{POS INDONESIA}

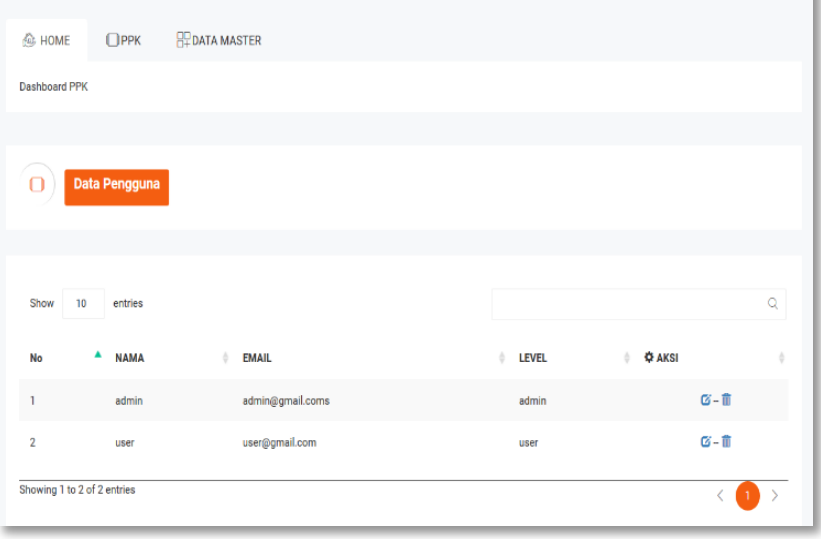

\section{Gambar 4.18 Tampilan Output Data Pengguna}

6. Tampilan Output Cetak Penerimaan Kas Perhari dan Perbulan

Tampilan output cetak penerimaan kas perhari merupakan halaman yang digunakan oleh aktor untuk mencetak penerimaan kas PT. Pos Indonesia (persero) Kota Jambi. Adapun tampilan cetak penerimaan kas perhari dapat dilihat pada gambar 4.19 berikut ini :

Pt Pos Indonesia Persero Jam

Telp : (0741)22139-5117

JL. Sultan Thaha No.5

\begin{tabular}{|c|c|c|c|c|c|c|}
\hline \multicolumn{7}{|c|}{ Laporan Penerimaan Kas } \\
\hline & No & JENIS BIAYA & KETERANGAN BIAYA & NILAI & PERB & BSU PENERIMAAN \\
\hline & 1 & PENERIMAAN KAS & PERANGKO 3000 & 3000 & 210 & Rp. 630000, : \\
\hline & 2 & PENERIMAAN KAS & PERANGKO 6000 & 6000 & 324 & Rp. 1044000 \\
\hline & 3 & PENERIMAAN KAS & PERANGKO 7000 & 7000 & 230 & Rp. 1610000 \\
\hline & 4 & PENERIMAAN KAS & PERANGKO 8000 & 8000 & 100 & Rp. 800000 ; \\
\hline & 5 & PENERIMAAN KAS & PERANGKO 8000 & 8000 & 120 & Rp. 080000 : \\
\hline & 6 & PENERIMAAN KAS & SURAT KLLAT KHUSUS & 2132000 & 1 & Rp. 2132000 \\
\hline & 7 & PENERIMAAN KAS & PERANGKO 0000 & 3000000 & 5 & Rp. 15000000 \\
\hline & & & TOTAL & & & Rp. 23.070.000. \\
\hline
\end{tabular}

\section{Gambar 4.19 Tampilan Output Cetak} Penerimaan Kas Perhari 
Account: Vol 6 No 2. Kristeria, Ayu Feranika, Gunardi,

Adapun tampilan cetak penerimaan kas perbulan dapat dilihat pada gambar 4.20 berikut ini :

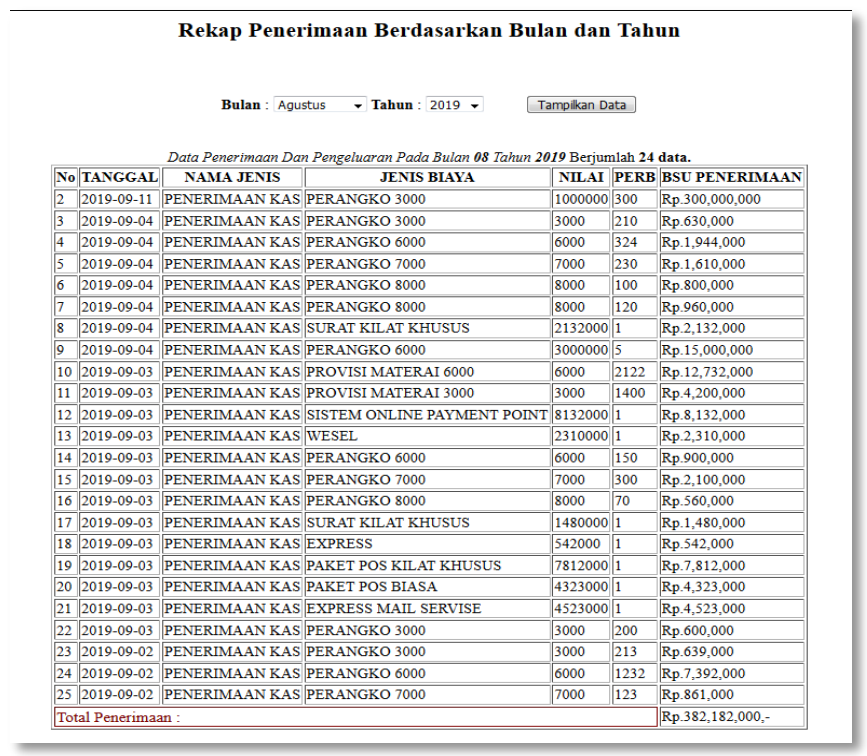

\section{Gambar 4.20 Tampilan Output Cetak Penerimaan Kas Perbulan}

\section{Tampilan Output Cetak Pengeluaran Kas Perhari dan Perbulan}

Tampilan output cetak pengeluaran kas perhari merupakan halaman yang digunakan oleh aktor untuk mencetak pengeluaran kas PT. Pos Indonesia (persero) Kota Jambi. Adapun tampilan cetak pengeluaran kas perhari dapat dilihat pada gambar 4.21 berikut ini :

Pt Pos Indonesia Persero Jambi

JL. Sultan Thaha N0.5

\section{Laporan Pengeluaran Kas}

Dicetak poda : Fri-13092019

\begin{tabular}{|c|c|c|c|c|c|}
\hline No & JENIS BIAYA & KETERANGAN BLAYA & NLAI & PERB & BSU PENGELUARAN \\
\hline 1 & PENGELUARAN KAS & TRANSPORT & 1300000 & 1 & Rp 1300000 : \\
\hline 2 & PENGELUARAN KAS & BBU GENSET & 50000 & 1 & $R_{p} .50000$; \\
\hline 3 & PENGELUARAN KAS & GAI PEGANA 1 & 1000000 & & RP. O; \\
\hline \multicolumn{5}{|c|}{ TOTAL } & RP. 1,350,000; ; \\
\hline
\end{tabular}

\section{Gambar 4.21 Tampilan Output Cetak} Pengeluaran Kas Perhari
Adapun tampilan cetak pengeluaran kas perbulan dapat dilihat pada gambar 4.22 berikut ini:

Rekap Pengeluaran Berdasarkan Bulan dan Tahun

Bulan : Agustus $\square$ Tahun : $2019-$ Tampikan Data

\begin{tabular}{|c|c|c|c|c|c|c|}
\hline \multicolumn{7}{|c|}{ Data Penerimaan Dan Pengeluaran Pada Bulan 08 Tahun 2019 Berjumlah 10 data. } \\
\hline No & TANGGAL & NAMA JENIS & JENIS BIAYA & NILAI & PERB & BSU PENGELUARAN \\
\hline 2 & $2019-09-04$ & PENGELUARAN KAS & GAJI PEGAWAI 1 & 1000000 & & Rp.0 \\
\hline 3 & 2019-09-04 & PENGELUARAN KAS & BBM GENSET & 50000 & 1 & Rp. 50,000 \\
\hline 4 & 2019-09-04 & PENGELUARAN KAS & TRANSPORT & 1300000 & 1 & Rp. $1,300,000$ \\
\hline 5 & $2019-09-03$ & PENGELUARAN KAS & BBM GENSET & 50000 & 1 & Rp. 50,000 \\
\hline 6 & $2019-09-03$ & PENGELUARAN KAS & TRANSPORT & 300000 & 1 & Rp. 300,000 \\
\hline 7 & $2019-09-02$ & PENGELUARAN KAS & GAJI PEGAWAI 2 & 2300000 & 5 & Rp. $11,500,000$ \\
\hline 8 & 2019-09-02 & PENGELUARAN KAS & GAJI PEGAWAI 1 & 3000000 & 12 & Rp. $36,000,000$ \\
\hline 9 & $2019-09-02$ & PENGELUARAN KAS & GAJI WAKIL KEPALA KANTOR & 4000000 & 1 & Rp. $4,000,000$ \\
\hline 10 & $2019-09-02$ & PENGELUARAN KAS & TRANSPORT & 1200000 & 1 & Rp. $1,200,000$ \\
\hline 11 & 2019-09-02 & PENGELUARAN KAS & GAJI KEPALA KANTOR & 5000000 & 1 & Rp. $5,000,000$ \\
\hline Tot & tal Pengeluar & & & & & Rp. $59,400,000,-$ \\
\hline
\end{tabular}

\section{Gambar 4.22 Tampilan Output Cetak Pengeluaran Kas Perbulan}

\section{Tampilan Output Cetak Penerimaan dan Pengeluaran Kas Perbulan}

Tampilan output cetak penerimaan dan pengeluaran kas merupakan halaman yang digunakan oleh aktor untuk mencetak penerimaan dan pengeluaran kas PT. Pos Indonesia (persero) Kota Jambi. Adapun tampilan cetak penerimaan dan pengeluaran kas dapat dilihat pada gambar 4.23 berikut ini: 
Account: Vol 6 No 2. Kristeria, Ayu Feranika, Gunardi,

Rekap Berdasarkan Bulan dan Tahun

Bulaw : Danuarl - Tabux: 2019 - Temollian Das

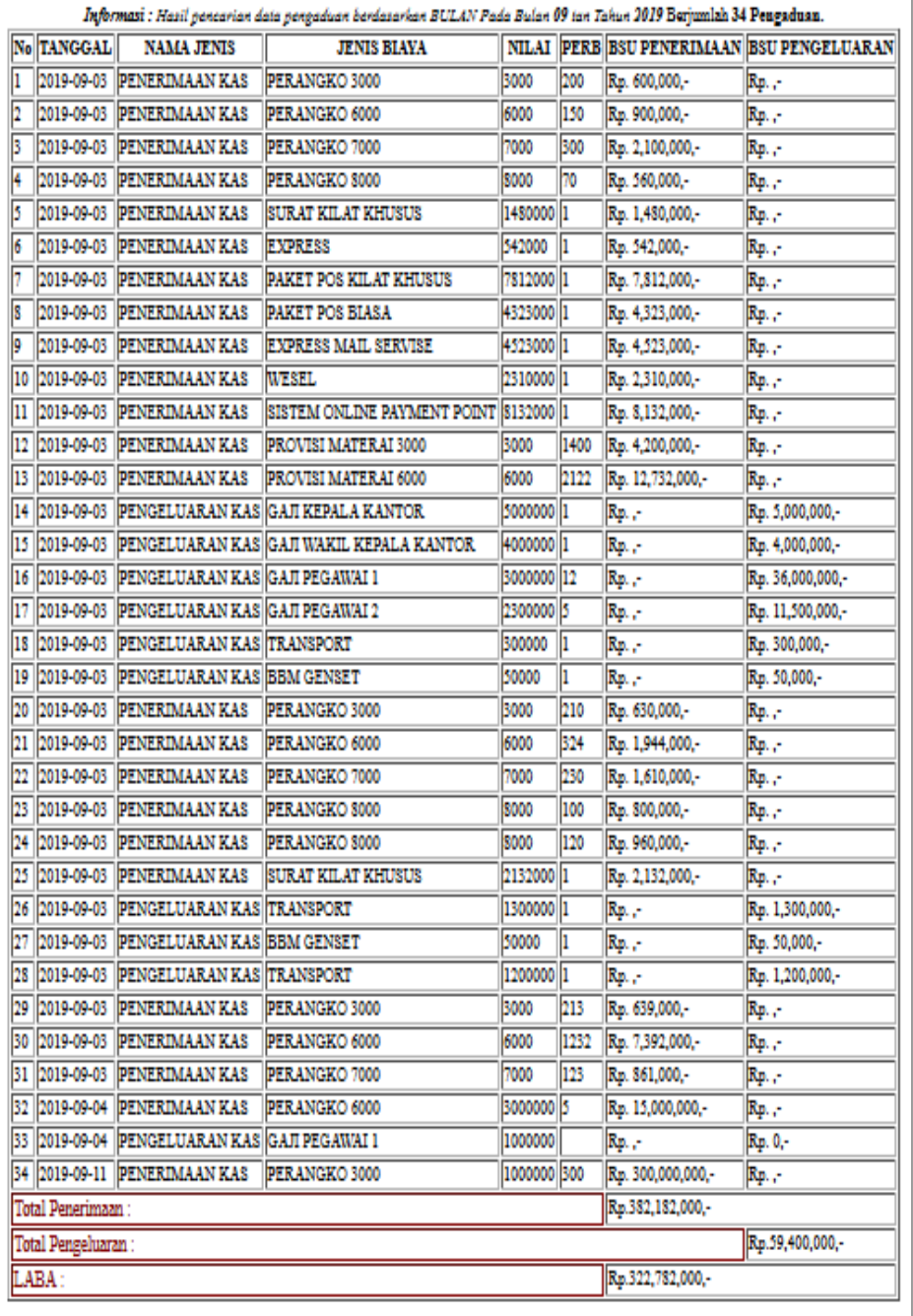

Gambar 4.23 Tampilan Output Cetak Penerimaan dan Pengeluaran Kas Perbulan

\section{Pengujian Sistem}

Pengujian sistem adalah tahap pengujian terhadap hasil rancangan yang telah dibuat. Pengujian sistem meliputi pengujian menu login, input, output dan laporan. Pada tahapan ini penulis melakukan pengujian terhadap sistem yang telah dihasilkan. Pengujian ini dilakukan agar sistem yang telah dibuat sesuai dengan tujuan yang ingin dicapai penulis serta menghindari kesalahan-kesalahan dalam sistem. Hasil dari pengujian sistem ini menunjjukkan bahwa sistem dapat di aplikasikan dengan baik.

\section{KESIMPULAN}

Berdasarkan hasil analisis, implementasi, dan pengujian yang telah dilakukan oleh penulis maka dapat ditarik kesimpulan dari uraian yang telah dijabarkan sebelumnya diantaranya sebagai berikut :

1. Sistem yang berjalan pada saat ini dalam pengelolaan penerimaan dan pengeluaran kas di PT. Pos Indonesia (Persero) kota Jambi belum sepenuhnya dilakukan dengan menggunakan media Informasi Teknologi yang memadai. Sebagian proses pencatatan penerimaan dan pengeluaran kas belum sepenuhnya terkomputerisasi seperti penggunaan Buku Basar, serta penggunaan aplikasi bawaan yaitu Microsoft Excel, penggunaan tersebut mengharuskan staf terkait membutuhkan waktu yang relatif lama, baik dari segi pencatatan, perhitungan hingga pembuatan laporannya.

2. Sistem informasi akuntansi penerimaan dan pengeluaran kas ini dapat mempermudah pegawai PT. Pos Indonesia (Persero) kota Jambi, seperti proses penginputan dana kas masuk dan dana kas keluar.

\section{KETERBATASAN}

1. Tampilan rancangan sistem informasi akuntansi penerimaan dan pengeluaran kas masih memiliki tampilan yang sederhana.

2. Sistem ini dibuat hanya untuk mencatat transaksi yang sudah masuk dan transaksi yang telah keluar oleh bagian kasir internal dan bagian keuangan saja, bukan oleh bagian pelayanan.

3. Jika kasir internal ingin menghapus beberapa data, kasir internal harus menghapus data satu persatu karena sistem tidak memiliki fasilitas menghapus data keseluruhan. 


\section{DAFTAR PUSTAKA}

Achmad, Solichin. (2016). "Pemrograman Web Dengan Php Dan Mysql".

Achmad, Solichin. (2010). "MySQL 5 Dari Pemula Hingga Mahir”.

Andi, Esteria, N. W., dkk, (2016). 'Analisis Sistem Akuntansi Penerimaan dan Pengeluaran Kas Pada PT Hasjrat Abadi Manado. Jurnal Berkala Ilmiah Efisiensi Vol. 16 No. 04, 1087-1097.

Damayanti dan Sulistiani, H. (2017). 'Sistem Informasi Pembayaran Biaya Sekolah Pada sd Ar-raudah Bandar Lampung', Jurnal TeknoInfo, Vol. 11, No. 2, 1-5.

Diana, A dan Setiawan, L. (2010) Sistem Informasi Akuntansi. Yogyakarta:

Diana, dkk. (2018). 'Akuntansi Penerimaan dan Pengeluaran Kas Pada PT. Sinar Harapan Anugrah Sejahtera Medan. Jurnal Bisnis Kolega, Vol 4 No. 2, 2621-8291.

Fachtareza, Sucahyono. (2017). 'Prosedur Pengeluaran Kas Pada PT PLN (Persero) Udiklat Semarang'.Universitas Diponogoro.

Hery. (2015). Akuntansi Keuangan Menengah I. Edisi 1. Jakarta : Bumi Aksara.

Indrajani. (2015). Database Design (Case Study All in One). Jakarta: PT Elex Media Komputindo.

Mulyadi, (2016). Sistem Akuntansi. Edisi Keempat. Salemba empat. Jakarta.

Robi, Yanto. (2016). Manajemen Basis Data Menggunakan MySQL, Deepublish, Yogyakarta.

Rohi, Abdulloh. (2018). 7 in 1 Pemrograman Web untuk Pemula. Jakarta: Elex Media Komputindo.

Sri, Mulyani. (2016). Sistem Informasi Manajemen. Bandung: Abdi Sistematika.

Syaifudin, dan Ardani, F.P. (2017). 'Sistem Informasi Akuntansi Penelrimaan dan Pengeluran dalam Meningkatkan Pengendalian Internal Atas Pendapatan Pada RSUP Dr. Kariadi Semarang'. Jurnal Riset Akuntansi Keuangan, Vol. 2 No. 2. 